\title{
Aberrant immunophenotypes in acute lymphoblastic leukemia
}

\author{
Miguel E. Cuéllar-Mendoza ${ }^{1}$, Francisco R. Chávez-Sánchez ${ }^{1}$, Elisa Dorantes-Acosta², \\ Blanca M. Arsuaga-Jiménez ${ }^{3}$, and Marta Zapata-Tarrés ${ }^{3 *}$
}

${ }^{1}$ Facultad de Medicina, Universidad Nacional Autónoma de México; ${ }^{2}$ Departamento de Hemato-Oncología, Hospital Infantil de México Federico Gómez; ${ }^{3}$ Departamento de Oncología, Instituto Nacional de Pediatría. Mexico City, Mexico

\begin{abstract}
Acute lymphoblastic leukemia (ALL) is the most prevalent hematologic neoplasia worldwide. To classify leukemia, we analyzed the immunophenotypic characteristics in the neoplastic cells obtained with antibodies by cell flow cytometry or immunohistochemistry. The aberrant immunophenotypes are antigen expression patterns that differ from the normal hematopoietic maturation process, which can include some different lineage antigens such as myeloid antigens in ALL or asynchronous expression of antigens. These aberrant immunophenotypes have been studied as prognostic factors and residual disease markers. In this review, some aspects of aberrant immunophenotypes are addressed, including definition, epidemiology, and potential uses.
\end{abstract}

Key words: Immunophenotypes. Leukemia. Lymphoblastic. Hematologic. Review.

\section{Inmunofenotipos aberrantes en la leucemia linfoblástica aguda}

\section{Resumen}

La leucemia linfoblástica aguda es la neoplasia hematológica más prevalente en el mundo. Para clasificar la leucemia se utilizan características inmunofenotípicas en las células neoplásicas que se pueden observar con anticuerpos en la citometría de flujo o mediante inmunohistoquímica. Los inmunofenotipos aberrantes son los patrones de expresión de los antígenos que difieren del proceso normal de maduración hematopoyética, y pueden incluir antígenos de linajes diferentes, como antígenos mieloides en la leucemia linfoblástica aguda, o la expresión asincrónica de antígenos. Estos inmunofenotipos aberrantes se han estudiado como factores de pronóstico y como marcadores de enfermedad mínima residual. En esta revisión se abordan algunos aspectos de los inmunofenotipos aberrantes, incluyendo su definición, epidemiología y usos potenciales.

Palabras clave: Inmunofenotipos. Leucemia. Linfoblástica. Hematología. Revisión.

\section{Correspondence:}

*Marta Zapata-Tarrés

E-mail: mzapatatarres@gmail.com
Date of reception: 18-10-2019

Date of acceptance: 11-03-2020

DOI: 10.24875/BMHIM.20000171
Available online: 13-11-2020 Bol Med Hosp Infant Mex. 2020;77(6):287-292

www.bmhim.com 1665-1146/@ 2020 Hospital Infantil de México Federico Gómez. Published by Permanyer. This is an open access article under the CC BY-NC-ND license (http://creativecommons.org/licenses/by-nc-nd/4.0/). 


\section{Introduction}

Acute lymphoblastic leukemia (ALL) is a malignant transformation of hematopoietic progenitor cells in the blood marrow, blood, and extramedullary sites, characterized by the accumulation of altered hematopoietic progenitors in those sites ${ }^{1}$. ALL is the most common malignancy in childhood ${ }^{2,3}$. In the United States, it has a global incidence of 1.7 cases $/ 100,000$ inhabitants ${ }^{4}$, while in middle-income countries like Mexico, the incidence is higher: $7.98 / 100,000$ inhabitants $^{5}$. The first classification of ALL was based on the morphological criteria of the French-American-British classification, which includes the nucleus/cytoplasm ratio, nucleoli, size of the cell, vacuoles ${ }^{6}$, and the fact that the bone marrow must contain at least $20 \%$ of blast cells (Table 1) ${ }^{7}$. After the introduction of flow cytometry in clinical diagnosis, lineage markers to classify leukemia as B cell origin or T cell origin have been widely used. This method revealed that some abnormal antigens can appear in the neoplastic cells.

\section{Common immunophenotype markers in ALL}

At present, leukemia can be classified into $B$ cell or $T$ cell types, depending on the markers that the neoplastic cells express in a flow cytometry assay. The most common cellular markers are immunoglobulins (Ig): CD19 or CD22 for B cell neoplasia, and CD3 and T cell receptor (TCR) for T cell neoplasia (Table 2) ${ }^{8,9}$. These markers are present in the non-neoplastic counterpart and represent well-characterized molecules that are typical for these lineages. Even in the European Group for Immunological Characterization of Acute Leukemia (EGIL) first proposal for the classification of acute leukemia, it was recognized that some of the ALL express myeloid antigens ${ }^{9}$, which are not present in their normal counterpart cells. Further studies defined biphenotypic and bilineal leukemia. At present, in Mexico, some efforts have been made to establish an immunological classification for acute leukemia (Table 3).

Khalidi et al. identified non-significant differences between primary and relapsed ALL patients ${ }^{10}$.

\section{Biphenotypic and bilineal leukemia}

EGIL defines biphenotypic leukemia as a group in which blasts express simultaneously myeloid and lymphoid antigens, with a score of $\geq 2$ points present in two different lineages (Table 4$)^{11}$.
Table 1. French-American-British classification for acute lymphoblastic leukemia ${ }^{46}$

\begin{tabular}{|l|l|l|}
\hline Type & Morphology & Immunophenotype \\
\hline L1 & $\begin{array}{l}\text { Homogeneous blasts, } \\
\text { regular nucleus, } \\
\text { homogenous chromatin, } \\
\text { small or inexistent } \\
\text { nucleoli, mild basophilia }\end{array}$ & $\begin{array}{l}\text { B cell: CD19, CD22, CD79a, CD10, } \\
\text { CD20, Ig cytoplasmic, or } \\
\text { superficial } \\
\text { T cell: CD3, CD7, CD5, CD2, or CD4 }\end{array}$ \\
\hline L2 & $\begin{array}{l}\text { Irregular nucleus, } \\
\text { heterogeneous } \\
\text { chromatin, and large } \\
\text { nucleoli }\end{array}$ & $\begin{array}{l}\text { B cell: CD19, CD22, CD79a, CD10, } \\
\text { CD20, Ig cytoplasmic, or } \\
\text { superficial }\end{array}$ \\
\hline T3 cell: CD3, CD7, CD5, CD2, or CD4 \\
$\begin{array}{l}\text { Large blasts, prominent } \\
\text { nucleoli, abundant } \\
\text { cytoplasm, vacuolation } \\
\text { covering the nucleus }\end{array}$ & $\begin{array}{l}\text { B cell: CD19, CD22, CD79a, CD10, } \\
\text { CD20, Ig cytoplasmic, or } \\
\text { superficial }\end{array}$ \\
T cell: CD3, CD7, CD5, CD2, or CD4
\end{tabular}

Ig: immunoglobulin.

Table 2. Markers used for lineage classification of acute lymphoblastic leukemia

\begin{tabular}{|l|l|}
\hline Lineage & Markers \\
\hline B cell & $\begin{array}{l}\text { Surface immunoglobulins, cytoplasmic light chains, } \\
\text { CD19, CD22, CD79 }\end{array}$ \\
\hline T cell & $\begin{array}{l}\text { CD3 (cytoplasmic or membrane), CD2, CD5, CD8, T } \\
\text { cell receptor }\end{array}$ \\
\hline
\end{tabular}

Bilineal leukemia is defined as a heterogeneous group of hematopoietic malignancies, with blasts that cannot be classified as myeloid or lymphoid, or blasts from both lineages ${ }^{12}$.

Not only EGIL, but the World Health Organization also proposed criteria for mixed-phenotype blasts in the Classification Tumors of Hematopoietic and Lymphoid Tissues 2016 update (Table 5) ${ }^{11-13}$. This classification comprises bilineal and biphenotypic leukemia into this entity and includes $2-5 \%$ of all leukemia diagnosis. No threshold level of antigen expression is defined for the diagnosis ${ }^{14}$.

\section{Aberrant immunophenotypes in ALL}

Some leukemias show antigen expression of two cellular lineages but not all the biphenotypic, bilineal, or mixed phenotype criteria. The expression of these antigens has been termed anomalous or aberrant ${ }^{15}$. In $B$ cell ALL, myeloid antigens are the best-studied antigens. Another definition of aberrant immunophenotypes is the antigen expression patterns in neoplastic 
Table 3. Markers proposed in the National Consensus of Acute Leukemia Phenotyping in Mexico ${ }^{47}$

\begin{tabular}{|l|l|c|l|c|}
\hline Type of ALL & Lineage & Differentiation/Maturation & Subclassification & \multicolumn{1}{c|}{ Optional } \\
\hline B cell precursor & $\begin{array}{l}\text { CD19 } \\
\text { Cytoplasmic CD79 }\end{array}$ & CD34, CD45, CD20, CD38 & $\begin{array}{l}\text { CD10, Ig superficial, } \mu \\
\text { cytoplasmic chains }\end{array}$ & TdT, CD13, CD33 \\
\hline T cell precursor & CD3, CD7 & CD34, CD45, TdT, CD1a, CD99 & - & CD2, CD4, CD5, CD8, CD13, CD33
\end{tabular}

ALL: acute lymphoblastic leukemia; TdT: terminal deoxynucleotidyl transferase; Ig: immunoglobulin.

Table 4. EGIL criteria for biphenotypic leukemia

\begin{tabular}{|l|c|c|c|}
\hline Points & B cell lineage & T cell lineage & Myeloid lineage \\
\hline 2 & CD7, CD22, IgM & CD3, TCR & MP0 \\
\hline 1 & CD19, CD20, CD10 & $\begin{array}{r}\text { CD2, CD5, CD8, } \\
\text { CD10 }\end{array}$ & CD117, CD13, CD33 \\
\hline 0.5 & TdT y CD24 & TdT, CD7, CD1a & CD14, CD15, CD64 \\
\hline
\end{tabular}

*For the diagnostic of biphenotypic leukemia, myeloperoxidase (a major myeloid antigen), and another major antigen of B or T cell origin should be present. The diagnostic of aberrant immunophenotypes is determined with one point in two different categories.

EGIL: European Group for Immunological Characterization of Acute Leukemia; MPO: myeloperoxidase; TCR: T cell receptor; TdT: terminal deoxynucleotidyl transferase.

cells that differ from the normal antigens in the maturation process of hematopoietic cells. In essence, this includes other lineage antigens: myeloid antigens in ALL, B cell antigens in T cell ALL or vice versa, or antigen asynchrony (when earlier phase antigens are expressed in mature cells). The threshold for positivity ${ }^{10,16}$ is $20-30 \%$ of the isolated leukemic cells ${ }^{17}$.

Conflicting information on the prevalence of aberrant antigens has been reported. These differences can be explained by the variation of antibodies against antigens, diverse cutoff levels, or the samples used in the analysis $^{18}$. Seegmiller et al. reported $86.5 \%$ of myeloid antigens in 200 cases of B lineage ALL and $9 \%$ of $T$ cell antigens in their series ${ }^{19}$. The Brazilian study by Lopes et al. showed only $49.2 \%$ of myeloid expression in $T$ and $B$ cell $A L L^{20}$. In turn, Bachir et al. studied a population of Moroccan children and found myeloid expression in $46.3 \%$ of $B$ cell ALL and $22 \%$ of $T$ cell $\mathrm{ALL}^{21}$; other studies mentioned higher prevalence in $\mathrm{T}$ cell $A L^{22}$. Ibrahim et al. mentioned a percentage as low as $5 \%$ of myeloid expression ${ }^{18}$. From these reports, it is assumed that incidence varies depending on the population studied. The gathered information is consistent in the fact that the expression of myeloid antigens is higher in B cell ALL. Furthermore, Khalidi et al. reported $T$ cell markers in $B$ cell $A L L, C D 3, C D 4$, and CD7, were expressed in $<5 \%$ of the cases $^{10}$. B cell
Table 5. WHO criteria for mixed-phenotype blasts

\begin{tabular}{|c|c|}
\hline Lineage & Markers \\
\hline Myeloid & $\begin{array}{l}\text { Myeloperoxidase or two of the following: CD11c, } \\
\text { non-specific esterase, CD14, CD64, lysozyme }\end{array}$ \\
\hline $\mathrm{T}$ lineage & Cytoplasmic or surface CD3 \\
\hline$B$ lineage & $\begin{array}{l}\text { Strong CD19 plus at least one of the following: CD79a, } \\
\text { cytoplasmic CD22 or CD10; or weak CD19 and two of } \\
\text { the following: CD79a, cytoplasmic CD22, or CD10 }\end{array}$ \\
\hline
\end{tabular}

WHO: World Health Organization.

markers in T cell ALL were expressed in $15 \%$ of the cases in the Sharma study, with CD79a and CD19 being the most commonly found ${ }^{23}$. Bhushan et al. reported a higher incidence of myeloid antigens in adults $^{24}$. However, these findings were not observed in other studies ${ }^{10,19}$. In Argentinian patients, Novoa et al. characterized the presence of antigen asynchrony in $\mathrm{B}$ cell ALL, with CD34+ CD20+ and CD34+ CD10- being the most frequently expressed phenotypes ${ }^{25}$. The differences found in these studies reported during the past 20 years were the main reason to do a review on this topic. Table 6 shows the studies and results from different authors ${ }^{15,16,18,26-28}$.

One of the most frequent aberrant myeloid markers is CD13, a glycoprotein with peptidase activity ${ }^{18}$ expressed in normal hematopoietic cells in the processes of maturation, from myeloblasts to granulocytes. In the Seegmiller study, CD13 was the most common myeloid antigen present in ALL (54.5\%) $)^{19}$. Another antigen, CD33, is a transmembrane protein present in myeloblast with inhibitory functions, expressed in promyelocytes, monocytes, and erythrocyte ${ }^{29}$. CD33 was found in 43\% in the Seegmiller study. Other myeloid markers such as CD117 are not frequently expressed in ALL ${ }^{30,31}$. HLA-DR is more frequently found in $B$ cell precursors $A L L$ than in T cell ALL. NK markers, like CD56, have been found on $B$ cell $A L L$ in low percentages ${ }^{10}$. 
Table 6. Several studies of myeloid antigens as possible prognostic factors in patients with acute lymphoblastic leukemia

\begin{tabular}{|c|c|c|c|}
\hline Author & Year & Type of leukemia (B, T or both) & Results \\
\hline Tabernero et al. ${ }^{26}$ & 2001 & B & 13 cases with BCR/ABL (Abelson) translocation were positive for CD13 \\
\hline Yeneral et al. ${ }^{16}$ & 2002 & Both & $\begin{array}{l}\text { The patients positive to } \mathrm{CD} 13 \text { had better overall survival and disease-free } \\
\text { survival ( } 85 \text { vs. } 50 \% \text { and } 67 \text { vs. } 43 \% \text {, respectively) }\end{array}$ \\
\hline Vitale et al. ${ }^{27}$ & 2006 & Both & $\begin{array}{l}\text { No correlation was found between the expression of CD13 and the } \\
\text { disease-free survival or overall survival }\end{array}$ \\
\hline Noronha et al. ${ }^{15}$ & 2011 & Both & The positive myeloid group achieved more remission cases \\
\hline Supriyadi et al. ${ }^{28}$ & 2012 & Both & $\begin{array}{l}\text { The negative myeloid group got a better disease-free survival compared } \\
\text { with the positive myeloid group ( } 80 \mathrm{vs.} 67 \% \text { ) }\end{array}$ \\
\hline Ibrahim et al. ${ }^{18}$ & 2017 & Both & $\begin{array}{l}\text { CD13 positive group had complete remission and fewer blasts in bone } \\
\text { marrow, compared to the negative group }\end{array}$ \\
\hline
\end{tabular}

BCR: B cell receptor.

\section{Aberrant immunophenotypes as a prognostic factor}

At present, several contradictory results from different studies on this topic have emerged. In 2017, Kavianpour et al. ${ }^{30}$ discussed some studies that found a lower death rate in the positive myeloid group. However, the results of other authors are not consistent with this study $16,24,27,31$. Copeland and McGuire addressed the same problem ${ }^{32}$.

The Children's Cancer Group reported that the aberrant immunophenotype expression was not an adverse prognostic factor: 1557 children enrolled with $B$ or T cell ALL, but only $13.9 \%$ and $2.8 \%$, respectively, expressed positive myeloid antigens ${ }^{17}$. The research of the St Jude Children's Research Hospital in acute mixed lineage leukemia stated that lineage infidelity does not have prognostic significance ${ }^{33}$. Moreover, The Medical Research Council, in the United Kingdom, showed no prognostic significance of the expression of CD13 and CD33 ${ }^{34}$. Lopez et al. found a significantly higher platelet value in those patients with positive myeloid markers ${ }^{20}$. In adult patients, Yenerel et al. found differences in overall survival between the myeloid positive and negative groups ( 85 vs. $50 \%$ ); also, the disease-free survival was different (67 vs. $43 \%$ ), which was not consistent with previous studies ${ }^{16}$. In Indonesian patients treated with the ALL 2006 protocol, Supriyadi et al. found that leukemia-free survival analyses showed worse prognosis in the positive myeloid group: disease-free survival was $67 \%$ in the positive myeloid group versus $80 \%$ in negative myeloid patients ${ }^{28}$. Sharma et al. reported a lower number of peripheral blasts and lower white blood cell count in the myeloid positive group ${ }^{23}$, while Amirghofran et al. reported less significance in survival time in CD13 positive cases versus negative cases $^{35}$. Similar results were found in the Mexican study by Rodriguez et al., as well as a lower disease-free survival period ${ }^{36}$. Craddock et al. showed an increased relapse risk in CD13 positive cases $^{37}$, while Dalal et al. proposed a more aggressive treatment for ALL with this immunophenotype ${ }^{38}$.

Myeloid expression was observed in Philadelphia chromosome-positive ALL, both in children and adults. This chromosomic aberration is considered as bad prognostic in adults. Other chromosomic abnormalities with an expression of myeloid antigens reported by Khalidi et al. were the deletion of band 11q23 and translocations involving this chromosome ${ }^{10}$. The expression of CD5 in B cell ALL has been reported in association with small supernumerary marker chromosomes ${ }^{39}$.

\section{Immunophenotypic detection of minimal residual disease}

Over the past decades, a considerable effort has been made in developing methods to detect residual leukemia in patients that had achieved clinical remission. Minimal residual disease (MRD) is defined as the detection of at least $0.01 \%$ leukemic blasts per mononuclear or total nucleated cells ${ }^{40}$. The methods for MRD detection are the polymerase chain reaction with fusion gene transcripts or Ig/TCR gene rearrangements by flow cytometry ${ }^{41,42}$.

In 1990, Campana et al. studied the asynchronous expression and lineage infidelity and detected minimal disease (35\%) and operationally leukemia-specific. 
Only in two of 35 cases, the characteristics in the cells changed $^{43}$. In 1997, San Miguel et al. reported that immunophenotypic aberrancies were useful in predicting relapse and MRD in acute myeloid leukemia ${ }^{44}$.

García-Vela et al. characterized four different types of aberrant immunophenotypes or leukemia-associated immunophenotypes that can be detected by flow cytometry, which include lineage infidelity, asynchronous antigen expression, ectopic antigen expression (expression of markers outside the thymus), and antigen overexpression. Therefore, the study of these antigens was suggested for MRD, as they found a high frequency of aberrancies ${ }^{45}$.

In 1999, Lucio et al. performed multicentric studies to detect MRD with flow cytometry, with positive results detecting malignant lymphocytes from normal lymphoblasts $^{46}$. Several subsequent studies have demonstrated the same results ${ }^{47,48}$. Gaipa et al. mentioned that leukemia-associated immunophenotypes are widely applicable, rapid, and direct but operator-dependent and require standardization ${ }^{42}$. Campana emphasizes the use of large antibody panels and interpretation expertise $^{41}$. At present, six to eight-color flow cytometry methods are used for leukemia immunophenotyping in $M_{R D}{ }^{42}$. This approach was useful in the Dhahran Health Center study, where they identified six MRD positive cases in B ALL ${ }^{40}$. The Euroflow group is recently standardizing new leukemia immunophenotyping and MRD protocols, with a more significant number of immunological markers.

Aberrant immunophenotypes are antigens that differ from the typical expression pattern in hematolymphoid neoplastic cells. The incidence of this phenomenon varies from $5 \%$ to $86.5 \%$. This difference could be explained by several reasons. For example, in the study that showed an incidence of $86.5 \%$, several antigens that are generally not measured were considered. Conversely, in the series that considered the two most common myeloid antigens (CD13 and CD33), the percentage was much lower $(30-50 \%)$. Furthermore, the different laboratories or dilutions used for the antibodies, as well as the positivity threshold that some of the antigens showed in different studies, ranging from 20 to $30 \%$, should be considered. Another crucial variable is the different populations in the studies.

The potential role of aberrant immunophenotypes as a prognostic factor is still controversial. Some studies in low- and medium-income countries reveal that prognosis is different between myeloid positive and myeloid negative ALL. Contrastingly, in more prominent studies from the USA and UK, no significant differences were reported. In an Indonesian study, a different treatment protocol from the St. Jude protocol was used, which could explain the positive results in the evaluation of the disease remission. In patients with aggressive protocols, no evidence that the aberrant immunophenotypes change the prognostic of patients has been found. Other factors that need to be considered are the controversies between different populations and between low- and high-income countries.

In MRD, the detection of different antigens in the cell and the introduction of flow cytometry have been useful for diagnosis and treatment. However, as the panels are extensive, standardization is essential because they are operator-dependent.

\section{Ethical disclosures}

Protection of human and animal subjects. The authors declare that no experiments were performed on humans or animals for this study.

Confidentiality of data. The authors declare that they have followed the protocols of their work center on the publication of patient data.

Right to privacy and informed consent. The authors declare that no patient identifying information appears in this article.

\section{Conflicts of interest}

The authors declare no conflicts of interest.

\section{Funding}

None.

\section{Acknowledgments}

To the Instituto Nacional de Pediatría and the Hospital Infantil de México Federico Gómez. The authors would also like to thank the PhD program in Medical, Odontological and Health Sciences from UNAM and the grant from CONACYT.

\section{References}

1. Terwilliger T, Abdul-Hay M. Acute lymphoblastic leukemia: a comprehensive review and 2017 update. Blood Cancer J. 2017;7:1-12.

2. Mitchell C, Hall G, Clarke RT. Acute leukaemia in children: diagnosis and management. BMJ. 2009:338:1491-5.

3. Dorantes-Acosta E, Medina-Sanson A, Dávila-Ornelas K, López-Martínez B. Clasificación inmunológica de las leucemias agudas linfoblásticas del hospital infantil de México Federico Gómez, de acuerdo al EGIL (European Group for the Immunological Classification of Leukemia). Gac Mex Oncol. 2013;12:136-42. 
4. National Cancer Institute. National Cancer Institute, Surveillance Research Program. Cancer Statistics Review 1975-2013: age-adjusted SEER Incidence and US Death Rates and 5-year Relative Survival Rates. Bethesda, MD: National Cancer Institute; 2013. Available from: https:// www.seer.cancer.gov/archive/csr/1975_2013/results_single/sect_01_table.05_2pgs.pdf.

5. Rivera-Luna R, Velasco-Hidalgo L, Zapata-Tarrés M, Cárdenas-Cardos R, Aguilar-Ortiz MR. Current outlook of childhood cancer epidemiology in a middle-income country under a public health insurance program. Pediatr Hematol Oncol. 2017;34:43-50.

6. Zafar MN. FAB classification of acute lymphoblastic leukaemia (ALL) and its relevence to all in Karachi children. J Pak Med Assoc. 1985;35:233-6.

7. Chiaretti S, Zini G, Bassan R. Diagnosis and subclassification of acute lymphoblastic leukemia. Med J Hematol Infect Dis. 2014;6:e2014073.

8. Gajl-Peczalska KJ, Bloomfield CD, Nesbit ME, Kersey JH. B-cell markers on lymphoblasts in acute lymphoblastic leukaemia. Clin Exp Immunol. 1974; 17:561-9.

9. Bene MC, Castoldi G, Knapp W, Ludwig WD, Matutes E, Orfao A, et al. Proposals for the immunological classification of acute leukemias. Leukemia. 1995;9:1783-6.

10. Khalidi HS, Chang KL, Medeiros LJ, Brynes RK, Slovak ML, Murata-Collins JL, et al. Acute lymphoblastic leukemia: survey of immunophenotype, French-American-British classification, frequency of myeloid antigen expression, and karyotypic abnormalities in 210 pediatric and adult cases. Am J Clin Pathol. 1999:111:467-76.

11. Charles NJ, Boyer DF. Mixed-phenotype acute leukemia: diagnostic criteria and pitfalls. Arch Pathol Lab Med. 2017;141:1462-8.

12. Cernan M, Szotkowski T, Pikalova Z. Mixed-phenotype acute leukemia: state-of-the-art of the diagnosis, classification and treatment. Biomed Pap Med Fac Univ Palacky Olomouc Czech Repub. 2017;161:234-41.

13. Arber DA, Orazi A, Hasserjian R, Borowitz MJ, Beau Le MM, Bloomfield CD, et al. The 2016 revision to the World Health Organization classification of myeloid neoplasms and acute leukemia. Blood. 2016;127:2391-406.

14. Khan M, Siddiqi R, Naqvi K. An update on classification, genetics, and clinical approach to mixed phenotype acute leukemia (MPAL). Ann $\mathrm{He}$ matol. 2018;97:945-53.

15. Noronha EP, Marinho HT, Thomaz EB, Silva CA, Veras GL, Oliveira RA Immunophenotypic characterization of acute leukemia at a public oncology reference center in Maranhao, Northeastern Brazil. Sao Paulo Med J. 2011;129:392-401.

16. Yeneral MN, Atamer T, Yavuz AS, Kucukkaya R, Besisik S, Aktan M, et al. Myeloid antigen expression provides favorable outcome in patients with adult acute lymphoblastic leukemia: a single-center study. Ann Hematol. 2002;81:498-503

17. Uckun FM, Sather HN, Gaynon PS, Arthur DC, Trigg ME, Tubergen DG et al. Clinical features and treatment outcome of children with myeloid antigen-positive acute lymphoblastic leukemia: a report from the children's cancer group. Blood. 1997:90:28-35

18. Ahmed H, Tahir N, Obed F. Cytokines profiling as prognostic markers in newly diagnosed acute myeloid leukemia. Iraqi J Hematol. 2017;6:12-6.

19. Seegmiller AC, Kroft SH, Karandikar NJ, McKenna RW. Characterization of immunophenotypic aberrancies in 200 cases of B acute lymphoblastic leukemia. Am J Clin Pathol. 2009;132:940-9.

20. Lopes TC, Andrade KN, Camelo NL, Rodrigues VP, Oliveira RA. Influence of aberrant myeloid expression on acute lymphoblastic leukemia in children and adolescents from Maranhao, Brazil. Genet Mol Res. 2014;13:10301-7.

21. Bachir F, Bennani S, Lahjouji A, Cherkaoui S, Harif M, Khattab M, et al. Characterization of acute lymphoblastic leukemia subtypes in Moroccan children. Int J Pediatr. 2009;2009:674801.

22. Mazher N, Malik N, Imran A, Chughtai O, Chughtai AS. Aberrant expres sion of CD markers in acute leukemia. Ann Pak Inst Med Sci. 2013;9:99-102.

23. Sharma M, Sachdeva MS, Varma N, Varma S, Marwaha R. Characterization of immunophenotypic aberrancies in adult and childhood acute lymphoblastic leukemia: a study from Northern India. J Cancer Res Ther. 2016;12:620-6

24. Bhushan B, Chauhan PS, Saluja S, Verma S, Mishra AK, Siddiqui S, et al. Aberrant phenotypes in childhood and adult acute leukemia and its association with adverse prognostic factors and clinical outcome. Clin Exp Med. 2010;10:33-40.

25. Novoa V, Nuñez NA, Carballo OG, Lessa CF. Inmunofenotipos aberrantes en leucemias agudas en una población hospitalaria de Buenos Aires. Medicina. 2013;73:9-16.
26. Tabernero MD, Bortoluci AM, Alaejos I, López-Berges MC, Rasillo A, García-Sanz R, et al. Adult precursor B-ALL with BCR/ABL gene rearrangements displays a unique immunophenotype based on the pattern of CD10, CD34, CD13 and CD38 expression. Leukemia. 2001;15:406-14.

27. Vitale A, Guarini A, Ariola C, Meloni G, Perbellini O, Pizzuti M, et al. Absence of prognostic impact of CD13 and/or CD33 antigen expression in adult acute lymphoblastic leukemia. Results of the GIMEMA ALL 0496 trial. Haematologica. 2007:92:342-8.

28. Supriyadi E, Veerman AJ, Sutaryo S, Purwanto I, Vd Ven PM, Cloos J. Myeloid antigen expression in childhood acute lymphoblastic leukemia and its relevance for clinical outcome in Indonesian ALL-2006 protocol. J Oncol. 2012;2012:1-7.

29. Sato TN, Hayashi M. On the origin of species specificity of fibronectin. Immunological identification of a species-specific domain of human fibronectin. J Biochem. 1986:99:653-61.

30. Kavianpour M, Ketabchi N, Saki N. Prognostic significance of aberrant expression of CD markers in acute lymphoblastic leukemia. Mag Eur Med Oncol. 2017;10:164-9.

31. Suggs JL, Cruse JM, Lewis RE. Aberrant myeloid marker expression in precursor B-cell and T-cell leukemias. Exp Mol Pathol. 2007;83:471-3.

32. Copeland $E$, McGuire $E$. The biology and treatment of acute lymphoblastic leukemia in adults. Blood. 1995:85:1151-68

33. Rubnitz JE, Onciu M, Pounds S, Shurtleff S, Cao X, Raimondi SC, et al. Acute mixed lineage leukemia in children: the experience of St Jude children's research hospital. Blood. 2009;113:5083-9.

34. Hann IM, Richards SM, Eden OB, Hill FG. Analysis of the immunophenotype of children treated on the medical research council United Kingdom acute lymphoblastic leukaemia trial XI (MRC UKALLXI). Medical research council childhood leukaemia working party. Leukemia. 1998;12:1249-55.

35. Amirghofran Z, Shamseddin A, Shahriari M. Prognostic value of myeloid antigen expression in acute lymphoblastic leukemia. Med J Islam Repub Iran. 2000;14:111-4

36. Rodríguez-Rodríguez S, Pomerantz A, Demichelis-Gómez R, Barrera-Lumbreras G, Barrales-Benítez OV, Lopez-Karpovitch X, et al. Impact of aberrant antigens in the outcome of patients with acute leukemia at a referral institution in Mexico City. Rev Invest Clin. 2016;68:305-13.

37. Craddock KJ, Chen Y, Brandwein JM, Chang $\mathrm{H}$. CD13 expression is an independent adverse prognostic factor in adults with Philadelphia chromosome-negative B cell acute lymphoblastic leukemia. Leuk Res. 2013;37:759-64.

38. Dalal BI, Al Mugairi A, Pi S, Lee SY, Khare NS, Pal J, et al. Aberrant expression of CD13 identifies a subgroup of standard-risk adult acute lymphoblastic leukemia with inferior survival. Clin Lymphoma Myeloma Leuk. 2014;14:239-44

39. Mutreja D, Pati HP, Bansal D, Sharma RK, Jain S. Aberrant immunophenotypic expression of CD5 in a case of $b$ acute lymphoblastic leukemia: a case report. Indian J Hematol Blood Transfus. 2014;30:212-4

40. Amra N, Sheikh S, Abushullaih B, Al-Faris N, Al-Khatti A, Al-Sayed H Minimal residual disease program for acute lymphoblastic leukemia at Dhahran health center. J Appl Hematol. 2016;7:17-23.

41. Campana D. Minimal residual disease in acute lymphoblastic leukemia. Semin Haematol. 2009;46:100-6.

42. Gaipa G, Basso G, Biondi A, Campana D. Detection of minimal residual disease in pediatric acute lymphoblastic leukemia. Cytometry B Clin Cytom. 2013;84:359-69.

43. Campana D, Coustan-Smith E, Janossy G. The immunologic detection of minimal residual disease in acute leukemia. Blood. 1990;76:163-71.

44. San Miguel JF, Martínez A, Macedo A, Vidriales MB, López-Berges C González M, et al. Immunophenotyping investigation of minimal residual disease is a useful approach for predicting relapse in acute myeloid leukemia patients. Blood. 1997;90:2465-70.

45. Vela JA, Monteserin MC, Delgado I, Benito L, Oña F. Aberrant immunophenotypes detected by flow cytometry in acute lymphoblastic leukemia. Leuk Lymphoma. 2000;36:275-84.

46. Lúcio $P$, Parreira $A$, Van Den Beemd MW, Van Lochem EG Van Wering ER, Baars $E$, et al. Flow cytometric analysis of normal $B$ cell differentiation: a frame of reference for the detection of minimal residual disease in precursor-B-ALL. Leukemia. 1999;13:419-27.

47. Ladines-Castro W, Barragán-Ibañez G, Luna-Pérez MA, Santoyo-Sánchez A, Collazo-Jaloma J, Mendoza-García E, et al. Morphology of leukaemias. Rev Med Hosp Gen Mex. 2015;79:107-13.

48. Arriaga-Pizano L, Ramírez-Ramírez D, Prieto-Chávez J, Pelayo R, Ruiz-Argüelles $A$. Reporte de la primera reunión nacional de consenso para la inmunofenotipificación de leucemias agudas. Gac Med Mex. 2019;155:20-9. 